\section{Socialtjänstens användning av standardiserade klientbedömningsinstrument - ASI som retorik och praktik i två svenska kommuner}

I artikeln studeras hur ASI-intervjun är integrerad i den svenska socialtjänstens vardagliga arbete i två svenska kommuner, förutsättningarna att använda ASI och vilka behov den fyller för socialtjänsten. Analysen har två perspektiv; dels att ställa bruket av ASI-intervjun mot den idealmodell som IMS presenterat, dels att ur ett organisatoriskt perspektiv belysa om olika hierarkiska nivåer av socialtjänsten ser olika på nyttan och problemen med ASI-intervjun, vilket kan påverka användningen av instrumentet.

\section{Bakgrund}

I de nationella riktlinjerna för missbruks- och beroendevården (Socialstyrelsen 2007) anges användningen av standardiserade bedömningsinstrument som ett viktigt led i evidensbaseringen av missbrukarvården. Institutet för utveckling av metoder i socialt arbete (IMS) har som ett av sina ansvarsområden att utveckla och stödja användningen av bedömningsinstrument, för missbrukarvården i första hand det internationellt mest spridda ASI (Addiction Severity Index). Avsikten med ett bedömningsinstrument som ASI är att få en bild av den enskilda klientens problem inom olika livsområden för att kunna erbjuda adek-

\section{ABSTRACT}

\section{Abrahamson \& K. Tryggvesson:}

The use of standardized assessment tools within the social service organization ASI as rhetoric and praxis in two Swedish municipalities

AIM

The aim of the paper is to study how the Addiction Severity Interview (ASI) is integrated in the ordinary work of social services in two Swedish towns that use ASI regularly. According to an ideal model for using ASI, it should fulfil three functions: to be a structured tool for assessing client problems, to facilitate the follow-up of treatment measures for each client, and to form a basis for the systematic follow-up of treatment units. This paper asks specifically how ASI is used compared to this ideal ASI model, how ASI is viewed by the different hierarchical levels within the social service organisation, how the social worker's tasks are perceived, and how the use of ASI is followed up.

\section{METHODS}

Qualitative interviews were undertaken with staff at different levels within the social service organization in the two towns, which were chosen from a county known for its extensive use of ASI.

\section{RESULTS}

Although rhetorically the social workers have adopted the use of ASI, in practice. however, the use of ASI seemed rather far from ideal. The foremost advantage the social workers perceived with ASI was that it supplied basic information in an initial investigation of client needs. The problems connected to the use of ASI were that it is not suitable for all clients and that some clients are subjected to too many ASIs. Other problems were that it was hard to maintain sufficient 
quality in the use of ASI due to too high staff turnover and too few opportunities to conduct interviews. In spite of the well-known obstacles for efficient use of ASI, little control was undertaken to monitor use or how information from the interviews is used.

- CONCLUSIONS

The demand on social work to meet politician's expectations for service development can be in direct conflict with the practical considerations of the social service work, which may explain the shortfall between rhetoric and practice. From a political legitimacy point of view, it is more important that the social service organization is supported by the political funding sources than to meet demands for treatment efficiency. A loose coupling between rhetoric and practice allows for ASI to be adopted only rhetorically. while the regular work can continue to meet the practical considerations. The use of ASI cannot therefore be seen as a simple solution to the problems that the Swedish treatment system is struggling with.

KEYWORDS

ASI, evidence-based practice. social service organization. new institutional theory vata insatser om göra uppföljningar av gjorda insatser för att se vilken effekt de har haft. Dessa uppgifter kan i sin tur sammanställas för att styra missbruksvårdens verksamhet. Ytterligare ett framfört motiv är att skapa ett gemensamt språk för de vårdgivare som är engagerade i vården och därmed underlätta samordningen kring klienten.

Introduktionen av ASI i Sverige bör förstås mot bakgrund av den kritik som från flera håll riktats mot missbrukarvården. I en rapport över utvecklingen under åren 2000-2005 (Socialstyrelsen och Länsstyrelserna 2006) beskrivs insatserna som fragmentariska, ad hoc-mässiga och otillräckligt differentierade. Också från forskarhåll har omfattande kritik mot missbrukarvården förts fram. Den har bland annat handlat om att missbrukarvården historiskt styrts mer av vårdideologiska övertygelser, skiftande terapeutiska moden och politiska och ekonomiska konjunkturer än av forskningsbaserad kunskap om missbruksproblemens omfattning och karaktär, klienternas behov och konsekvenserna av olika interventioner (Blomqvist m.fl. 2007). Missbrukarvården har gång efter annan ställt ut förhoppningar om framtida framgångar i form av nya och löftesrika interventioner, förhoppningar som sedan har varit svåra att infria (se t.ex. Lindström 1992). Stora förväntningar har knutits till nya farmakologiska preparat, nya psykosociala behandlingsmetoder och nya samlade strategier, som t.ex. "matchning" som var 1990-talets numera avsomnade mantra (Blomqvist 2007). En del av orsakerna till detta kan vara att missbrukarvården varit ett jämförelsevis lågt prioriterat område inom välfärdspolitiken och att finansieringssystemen länge riktade ansvarigas intresse mera mot beläggningssiffror än mot resultat $\mathrm{i}$ form av förbättrade dryckes- eller drogvanor (Bergmark \& Oscarsson 1994). Statens intresse för missbrukarvården har emellertid ökat på senare år. Detta syns bl.a. i en ökad uppmärksamhet på dem som har svåra missbruksproblem (SOU 2004:3; SOU 2005:82), i utvecklingen av nationella riktlinjer för missbruks- och beroendevården (Socialstyrelsen 2007) samt i omfattande statliga ekonomiska bidrag till kommunerna för att utveckla missbrukarvården. Under perioden 2004-2007 har Länsstyrelserna fördelat sammanlagt 789 miljoner kronor till olika projekt i kommunerna (Socialstyrelsen och Länsstyrelserna 2008, 40). Avsikten är att stimulera kommunerna att utveckla metoder för en evidensbase- 
rad missbrukarvård. Implementeringen av ASI kan ses som ett led i dessa ambitioner. Idén om de evidensbaserade metoderna skall förstås i ljuset av de krav på utvärderingar av välfärdsstatens tjänster som följde med den ekonomiska recessionen på 1980-talet (Trinder \& Reynolds 2000). Med en evidensbaserad praktik förväntas hittills olösta problem lösas. Kraven på evidensbasering har emellertid mötts av omfattande kritik och debatt (se t.ex. Bergmark 2007; Bergmark \& Lundström 2007; Blomqvist 2002; 2007; Blomqvist \& Oscarsson 2006; Månsson 2000). I många kritikers ögon utgör idén om en evidensbaserad missbrukarvård bara det senaste i raden av löften om framtida lösningar som historiskt ställts ut inom detta fält.

\section{Bakgrund och tidigare forsk- ning \\ - ASI-intervjuns konstruktion}

ASI är en standardiserad strukturerad personlig intervju med i huvudsak förutbestämda svarsalternativ. Intervjun rör sju olika livsområden: alkoholanvändning, narkotikamissbruk, arbete och försörjning, familj och umgänge, brott och kriminalitet, samt fysisk och psykisk hälsa. Den första ASI-intervjun är en grundintervju, som innehåller 180 frågor för att kartlägga klientens tidigare liv och ge information om den nuvarande livssituationen. Grundintervjun tar för en van intervjuare en timme att genomföra. Den andra intervjun, som beräknas ta en halv timme att utföra, utgör en uppföljning och är begränsad till 150 frågor om klientens aktuella förhållanden. Förutom intervjun gör såväl intervjuaren som klienten skattningar av klientens problem och hur stort hjälpbehov klienten har. Genom standar- disering och strukturering skall intervjun ge likvärdiga svar av hög kvalitet om klientens verkliga situation oavsett vem som gör intervjun. För att uppnå detta krävs att intervjuaren förstår och är insatt i metoden, vilket kräver en speciell utbildning. ${ }^{1}$

\section{- Socialstyrelsens ideala modell för användande av ASI}

Användningen av ett bedömningsinstrument som ASI skall i huvudsak fylla tre funktioner i olika steg. I det första steget används ASI-intervjun för att skapa underlag för vidare kontakt med klienten och svara på frågor om inom vilka områden klienten har problem, vilka hjälpbehoven är, vilka insatser som är möjliga och var hjälpen bör sökas. ASI-intervjun förväntas tillföra en extra dimension genom att den på ett formaliserat sätt lyfter in klientperspektivet. Intervjuaren analyserar resultatet, jämför klientens skattningar med sina egna och presenterar dessa för och diskuterar dem med klienten. Med hjälp av den erhållna informationen skall en lämplig behandling kunna erbjudas.

Det andra steget utgörs av en uppföljningsintervju. Precis som i det första steget ingår en intervju med klienten, sammanställning, bearbetning och analys av intervjun samt ytterligare ett möte där klienten får ta del av bedömningen och diskutera den. Resultatet från uppföljningsintervjun kan jämföras med den första intervjun för att se om klientens situation förändrats och om ytterligare insatser behövs.

Det tredje steget utgörs av en systematisk uppföljning, eftersom ASI-intervjuer kan aggregeras till statistiska gruppsammanställningar. Det är möjligt att göra dels tvärsnittsbeskrivningar, t.ex. visa problembilder för alla klienter som under 
ett år kommit som nybesök till en vuxensektion, dels längdsnittbeskrivningar, t.ex. hur alkoholproblematiken hos en grupp som befinner sig i en specifik öppenvårdsenhet förändras under ett år. Beskrivningar kan utgöra underlag för verksamhetsplanering och utveckling. Nyström m.fl. (2003) ger exempel på frågor som en tvärsnittsbeskrivning kan besvara: om en enhet vänder sig till rätt målgrupp, om de olika insatserna svarar mot klientgruppens behov eller om insatserna behöver förändras. Om även uppföljningsintervjuer genomförs kan dessa också användas till längdsnittsbeskrivningar och verksamhetsuppföljning för att ge svar på om insatserna varit till hjälp för klienterna och/eller vissa undergrupper av klienter. Nyström m.fl. (2003) understryker dock att informationen bör vara tillförlitlig varför intervjuerna måste genomföras systematiskt och metodiskt och i stor omfattning.

\section{Spridningen av ASI}

ASI utvecklades av McLellan redan i slutet av 1970-talet i USA (McLellan m.fl 1992). Översättningen av ASI till svenska gjordes av Socialstyrelsen i mitten av 1990-talet (Andréasson m.fl. 1996). I en forskningsöversikt skriver Stenius \& Room (2004) att ASI framför allt används för att bedöma klienters hjälpbehov när de träder in i behandlingssystemet men att motiven att införa ASI har varierat i olika länder. De visar att ansträngningarna att bygga upp ett systematiskt dokumentationssystem baserat på ASI inte har varit framgångsrika och drar slutsatsen att instrumentet för den vanliga behandlingsverksamheten antagligen är för komplicerat, att det är alltför tidskrävande, samt att rollen som klienternas ombud kan vara besvärlig att kombinera med ingående registrering av t.ex. klienternas drogvanor och kriminalitet. Inte ens i Nederländerna, som är det land i Europa som använt ASI längst tid och där de flesta behandlingsenheterna använder ASI, har man lyckats åstadkomma några sammanställningar i verksamhetsstyrnings- eller forskningssyfte kunnat produceras (Broekman m.fl. 2004). Även om implementeringen av ASI i Sverige gått långsamt visar kartläggningar att användningen av ASI och andra standardiserade bedömningsinstrument har ökat under senare år. I en kartläggning genomförd 2003 av Socialstyrelsen (2004) använde $25 \%$ av alla Sveriges kommuner ASI. I en senare kartläggning (Abrahamson \& Tryggvesson 2008; Socialstyrelsen 2008a) uppger nästan $75 \%$ av alla kommuner att de använder något bedömningsinstrument i samband med utredning och problembedömning i klientärenden. Hälften av dessa använder ASI. I en annan aktuell kartläggning (Socialstyrelsen 2008b) av missbruks- och beroendevårdens öppenvård uppger mellan 40 och $45 \%$ av alla enheter att de använder ASI. I vilken grad dessa siffror avspeglar verkliga förhållanden är dock svårare att uttala sig om (för en diskussion se Alexanderson 2006).

Att ASI-användningen trots allt kanske inte är så omfattande som de nationella undersökningarna på enhetsnivå kan ge intryck av visar en studie av Engström \& Armelius (2005). I den svarar endast drygt hälften av alla som mellan 1996 och 2000 utbildats i ASI att de någon gång använt intervjun efter utbildningen. De som inte gjort det anger som vanligaste skäl att den inte passar deras klienter. Den vanligaste orsaken att använda intervjun är att få 
basinformation till en utredning eller som underlag för bedömning av klienten. Antalet genomförda intervjuer per deltagare är litet, framför allt inom socialtjänsten. Ett fåtal personer har gjort fler än 10 intervjuer och endast en liten del av dem som någonsin använt ASI-intervjun efter utbildningen har gjort en uppföljningsintervju.

\section{— Erfarenheter av implementeringsförsök av ASI i svensk socialtjänst}

Ett försök att införa bl.a. ASI i socialtjänsten i fyra kommuner under åren 20012002 redovisas av Alexanderson (2006). Projektet var väl förankrat, beslut hade tagits i socialnämnderna om att ansluta sig och all personal fick inledningsvis genomgå utbildning i metoderna. Resultatet av projektet visar emellertid att personalen inte använt grundintervjun för fler än 19 $\%$ av de nya klienterna och uppföljningsintervjun för 6 \% (a.a., 145). Siffrorna är baserade på socialakter, vilket kan förklara det låga antalet genomförda intervjuer jämfört med studier som baserats på enkätsvar av socialsekreterare, som uppskattar hur många intervjuer som genomförts. Skälen som angavs av de socialsekreterare som inte använt ASI var att intervjuerna var för tidskrävande, att de redan visste svaren om de kände klienterna och ibland av medicinska skäl var omäjliga att fullfölja. Det låga antalet uppföljningsintervjuer berodde på att klienterna var svåra att få tag i och att ett halvår var en för kort uppföljningsperiod. De förtjänster som nämndes med intervjun var att också andra livsområden blev belysta och inte enbart klientens missbrukssituation. Av de olika förutsättningar som Alexanderson bedömer saknas för en mer extensiv användning av bedömningsinstrument framträder särskilt personalomsättningen. Under projekttidens 2,5 år uppgick den till $47 \%$. Ytterligare ett år senare hade 79 $\%$ av de ursprungliga socialsekreterarna slutat. $^{2}$

Ett annat försök att implementera ASI redovisas i en utvärdering av Wikström \& Lindberg (2006). Mobilisera mot narkotika (MOB) finansierade under åren 2004-2005 aktiviteter avsedda att stimulera uppbyggnaden en vårdkedja baserad på användning av ASI i fyra kommuner. Utvärderingens resultat är i stort sett negativt, förutom en tendens till positiva effekter i en av kommunerna. I denna kommun hade all personal sedan tidigare gått utbildning i ASI men den användes endast sporadiskt. Det positiva resultatet beror på att projektet utfördes inom ramen för ordinarie organisation, vilket skapade förutsättningar för att det skulle kunna finnas kvar efter avslutningen. Också i den andra kommunen hade personalen tidigare utbildats i ASI utan att den egentligen kommit till användning. Trots nya direktiv om att $\mathrm{i}$ alla ärenden utföra ASI-intervju användes den selektivt i enklare ärenden. I mer komplicerade ärenden bedömdes klienterna vara för sårbara. Problemen definierades framför allt som tidsbrist. Projektet förblev särkopplat från den ordinarie verksamheten och det fanns inga tecken på anpassning till denna över tid. I den tredje kommunen ägnades det första året i huvudsak åt ASI-utbildning av personalen. Inga tecken fanns på ökad användning av ASI i verksamheten eller ökad samverkan i vårdkedja. I den fjärde kommunen hade man efter ett år egentligen inte kommit igång med arbetet. Den sammanfattande bedömningen av Wik- 
ström \& Lindberg (2006) är, att för att vissa kommuner skall kunna bilda en norm för andra är det nödvändigt att insatsen tas för given och blir institutionaliserad, vilket är en långsam organisatorisk process. Förutsättningarna för att utgöra norm finns egentligen bara i den första kommunen.

Ytterligare en snarlik statligt finansierad intervention med syfte att implementera bl.a. ASI är 'Vårdkedjeprojektet'(som pågick under 2004-2005 (Fäldt m.fl. 2007). Projektdeltagarna fick utbildning men endast $38 \%$ av dem använde ASI och $44 \%$ använde inte någon av metoderna (Fäldt 2007, 32). ASI skulle bl.a. användas som grund för behandlingsplaneringsmöten med klienterna. Ändå var det vanligt att ingen ASI-intervju hade gjorts innan mötena (Storbjörk 2007, 87). Var en ASI-intervju gjord kom den ofta ändå inte till användning. Socialtjänsten lutade sig istället mot den kunskap de sedan tidigare hade om klienten. Vid planeringen var valmöjligheterna även avsevärt inskränkta eftersom behandlingsalternativen var få: "Klienterna blev erbjudna och hade att välja mellan 12-stegsprogram och 12-stegsprogram eller mellan KBT och KBT” (a.a., 105). Vårdkedjeprojektets konklusioner är bl.a. att offentliga verksamheter inte skall involvera sig i projekt om de professionella och organisatoriska förutsättningarna för detta saknas. En annan är att en ensidig fokusering på specifika metoder strider mot forskningsläget och troligen inte leder till ett bättre liv för klienterna, särskilt om de specifika metoderna bara undantagsvis kan genomföras, vilket i Vårdkedjeprojektet var fallet med t.ex. ASI (Oscarsson \& Stenius a.a., $265 \mathrm{ff}$ ).

Erfarenheter av liknande slag finns också från ett försök att med medel från Länssty- relsen implementera ASI i åtta kommuner i nordvästra Stockholm under åren 2005 till 2007 (FoU-nordväst 2008). Ett av målen var att ASI skulle används i samtliga nyöppnade utredningar när den tvååriga projekttiden löpt ut. Trots att projektet var välförankrat på ledningsnivån i kommunerna och omfattande utbildningsinsatser gjorda av personalen visar resultatet att ASI-intervjuer användes endast i $43 \%$ av de nyöppnade utredningarna. Förklaringar utgörs bl.a. av att personalomsättning var över $50 \%$ under perioden, att en fjärdedel av alla chefer byttes ut och att fem av de åtta kommunerna genomgick organisatoriska förändringar. De som använde ASI-intervjun gjorde det i första hand för att få basinformation om klienten, i andra hand som underlag för vidare samtal med klienten, i tredje hand som vägledning för beslut om insats samt i sista hand för att skaffa sig kunskap om klientgruppen och för att utveckla verksamheten. De som avstod från att använda ASI-intervjun angav som skäl att en utredning redan gjorts inom kommunen, att klienten på grund av psykiska problem eller språksvårigheter hade svårt att förstå frågorna, att klienten var påverkad eller att kontakten var sporadisk.

Sammanfattningsvis visar erfarenheterna på stora svårigheter att införa standardiserade bedömningsinstrument (ASI) i socialtjänsten, trots att projekten varit statligt finansierade och väl förankrade i organisationernas ledning. Massiva utbildningsinsatser har gjorts och personalen uttrycker sig ofta i positiva ordalag om metoden. Ändå har ASI-intervjuer utförts endast i begränsad utsträckning. Projektutvärderingarna väcker frågor om varför ASI är så svårt att implementera. ${ }^{3}$ 
I vår undersökning är vi, till skillnad från ovan redovisade projektutvärderingar, intresserade av hur ASI används i den reguljära verksamheten. Vi vill särskilt peka på tre omständigheter som framstår som betydelsefulla för vår granskning av ASI-användningen i Mellanstad och Småstad:

1. Användarnas upplevelse av meningsfullhet med instrumentet. Den främsta nytta socialarbetarna uppfattar med ASI är att vid utredningsskede få ny information, så till vida klienten inte är känd sedan tidigare, något som endast gäller för en liten del av socialtjänstens klienter (Storbjörk \& Room 2007). Risken att intervjun inte ger ny information är därför stor. Detta gäller fram för allt för uppföljningsintervjuerna, som också sällan utförs. Relaterat till detta är frågan om vilken nytta socialarbetaren har av intervjun - oavsett dess resultat - ifall hon ändå är hänvisad till en speciell vårdform. Härtill kommer att socialarbetarna bedömer att vissa särskilt utsatta klientgrupper inte klarar av en ASI-intervju, som ses som omfattande och tidskrävande.

\section{Användarnas vana vid instrumentet.} För att kunna dra nytta av intervjuerna ställs krav på intervjuarnas kompetens och erfarenhet av att genomföra intervjuer. Frågan är om en vanlig svensk kommun har ett tillräckligt stort klientunderlag för att det skall vara möjligt att göra intervjuer i den omfattning som krävs för att upprätthålla kompetensen, särskilt med hänsyn till den höga personalomsättning som förefaller vara legio.

3. Organisatorisk samsyn och kontroll. Om projekten initierats från ledningsnivån men sedan inte på gräsrotsnivå genomförs på det sätt eller i den omfattning som beslutats blir några frågor viktiga: Har organisationen en samsyn på syftet och förtjänsterna med användningen av bedömningsinstrumentet? Erfarenheterna från projektutvärderingarna antyder att det kan finnas motsättning, där socialsekreterarna finner en inledande intervju relevant medan de är mindre motiverade att göra uppföljningsintervjuer. De senare intervjuernas syfte är relaterat till verksamhetsutveckling, vilket möjligen prioriteras högre på ledningsnivå. Hur ser de olika nivåerna på varandras arbetsuppgifter? Vilken kontroll skall brukas för att utredas om instrumentet används i enlighet de beslut som fattats?

\section{Teori och metod}

Som presenterats är syftet med artikeln att studera hur ASI-intervjun är integrerad i socialtjänstens vardagliga arbete i två svenska kommuner som använder ASI regelmässigt. Vi beskriver förutsättningarna att använda ASI och de behov ASI fyller för socialtjänsten. Två perspektiv är viktiga för analysen: Dels relaterar vi kommunernas användande av ASI-intervjun till en ideal modell av användandet, dels anlägger vi ett organisatoriskt perspektiv för att belysa socialtjänstens olika hierarkiska nivåers uppfattningar om ASI-intervjun, vilket kan påverka användningen av instrumentet.

Valet att intervjua representanter för olika hierarkiska nivåer inom socialtjänstorganisationen liksom valet av intervjufrågor är inspirerat av nyinstitutionell organisationsteori. Teorin har uppstått som en kritisk reaktion mot synen på organisationer som verktyg för rationellt genomförande av beslutade mål. En organisations handlande kan snarare ses som konstituerad 
av organisationsmedlemmarnas gemensamma handlande, som ofta är oreflekterat och styrt av regler och rutiner som tas för givna och sällan är klart artikulerade (Ahrne 1994; Johansson 2006; DiMaggio \& Powell 1991). Teorin är särskilt relevant för att studera en människovårdande organisation (Hasenfeld 1983) som socialtjänsten, som i flera avseenden skiljer sig från andra typer av byråkratiska organisationer. Det kännetäckande för människovårdande organisationer är att ha en hierarkisk organisation som litar till formella regler och rutiner för styrning samtidigt som den personal som till vardags möter klienterna eller patienterna, de s.k. gräsrotsbyråkraterna (Lipsky 1980), har stort handlingsutrymme i utförandet av sina arbetsuppgifter inom angivna ekonomiska ramar (Johansson 1992). Teorin riktar också uppmärksamhet på hur organisationers hierarkiska struktur ser ut, hur arbetet påverkas av politiska beslut och vilka rutiner och traditioner som finns för styrning (Hasenfeld 1983; Johansson 1992; 2002). Vidare, när det gäller att förstå förändringar inom organisationer, fokuserar teorin på aktörer och processer på lokal nivå snarare än officiella mål och officiell retorik (Johansson 2002).

Intervjuerna har genomförts med personal i två kommuner som vi kallat Mellanstad och Småstad. De två kommunerna valdes eftersom de ingår i ett län som enligt IMS kommit långt $\mathrm{i}$ användning av ASI (Siv Nyström, personlig kommunikation 20060512). De två kommunerna valdes sedan ut efter att kontakter med kommunerna i länet visat att ASI-användningen i dessa kommuner var särskilt vanlig. Mellanstad är länets största stad och har ungefär 125000 invånare, Småstad har ungefär 30000 invånare. I Mellanstad har ASI används i sju år och i Småstad i knappt två år. Vi genomförde tio intervjuer med fem personer i vardera kommun. Informanterna valdes från olika nivåer inom socialtjänstens missbrukarvård; en politiker med lång erfarenhet från socialnämnden, en verksamhetschef eller person i motsvarande ställning, en sektionschef alternativt gruppchef samt två handläggare, alternativt alkohol- och drogsamordnare. Intervjupersonerna valdes ut av ledningen i respektive kommun och intervjuerna genomfördes på deras arbetsplats.

Intervjuerna är semistrukturerade med likalydande frågor till samtliga personalkategorier för att kunna visa hur deras uppfattningar om ASI-användningen sammanfaller eller skiljer sig åt. Frågorna handlar om vad man ser som sina egna respektive övriga personalkategoriers viktigaste arbetsuppgifter och ansvarsområden, vilka de viktigaste motiven för att använda ASI är, hur instrumentet introducerades, för vilka klienter ASI används och för vilka inte, om erbjudanden om hjälp kan anpassas till den problembeskrivning ASI visar, förutsatt att gruppvisa sammanställningar och verksamhetsuppföljningar har gjorts, samt vilka uppföljande frågor om bruket av ASI som efterfrågas av olika nivåer inom organisationen. Varje intervju varade mellan ca 40 och 120 minuter. Intervjuerna spelades in digitalt och delar av dem har transkriberats.

Analysen av intervjusvaren är deskriptiv och har skett genom det Kvale (1997, 175) benämner meningskoncentrering, som innebär att intervjutexterna har sammanfattats i referat och koncentrerats till kortare tematiska beskrivningar. De teman vi har fokuserat på i analysen är hur våra 
respondenter uppfattar användningen av ASI, vilket vi jämför med den ideala modell som presenterats av IMS. Ytterligare ett tema för analysen är bruket av ASI ur ett organisatoriskt perspektiv, där vi jämför hur olika nivåer i organisationen ser på handläggarnas arbetsuppgifter, hur introduktionen och implementeringen av ASI gick till och vilken kontroll som skett av utvecklingen på sikt.

\section{Analys och resultat}

Resultaten presenteras under rubrikerna Den ideala modellen och Samstämmighet och kontroll. Under den första visar vi hur våra respondenter upplever ASI i förhållande till den ideala modellen som beskrivits tidigare - dvs. jämför ASI's retorik med dess praktik - och under den andra visar vi ASI-användningen ur ett organisatoriskt perspektiv, där vi även jämför retorik och praktik i den mån vi har information om detta.

\section{- Den ideala modellen}

Det sammanfattande intrycket av intervjuerna i Mellanstad och Småstad är att alla informanter är positiva till att använda ASI. Implementeringen har initierats och på olika sätt stöttats av verksamhetsledningarna. Våra informanter uppvisar en relativt stor samsyn om motiven för att använda ASI och denna samsyn överensstämmer i stort sett med den ideala modellens. Vissa skillnader finns dock, vilket vi återkommer till. På ett retoriskt plan tycks alla ha anammat metoden, fastän bruket i praktiken ligger ganska långt ifrån den ideala modellen. Vi skall här resonera och kring varför ASI inte används enligt den tänkta ideala modellen och utgår från de steg som anges i Nyström m.fl. (2003) och ser hur dessa förhåller sig till användningen av ASI i Mellanstad och Småstad.

\section{Steg I}

I både Mellanstad och Småstad säger informanterna att ASI-intervjun används i den initiala utredningen, dvs. enligt det första steget i den ideala modellen. Ett par av informanterna är dock lite osäkra på i vilken omfattning detta sker. Alla är ense om att ASI kan bidra med något positiv under utredningen. Den allmänna uppfattningen är att ASI genomförs och att den ger relevant information. Det anses också möjligt att utifrån denna information matcha klienter med en viss behandling och att det i praktiken finns ett visst utrymme att göra detta, även om handläggarna, särskilt i Mellanstad, upplever att möjligheterna till detta är begränsade, i all synnerhet om den inte sker på hemmaplan. De flesta tycker att intervjun ger socialsekreteraren stöd, ökar professionaliteten och skapar en trygg struktur i arbetet. Vidare lyfter många av de intervjuade fram ett rättssäkerhetsperspektiv: Alla klienter skall få samma bemötande och vårdmöjlighet oavsett vem som sköter deras ärende. Dessutom poängteras att metoden underlättar relationsskapande, ger mer information om olika aspekter i klienternas förhållanden, vilket ger mer informationsrika utredningar än tidigare.

Viss skillnad märks mellan de hierarkiska nivåerna inom socialtjänsten när förtjänsterna med ASI nämns. I båda kommunerna är politikerna positiva till att ASI används men är relativt diffusa om vad instrumenten innebär och förväntas göra. På handläggarnivå nämns bara de delarna som berör det konkreta klientbedömningsarbetet. När det gäller eventu- 
ella problem nämns risken för att instrumentet används på ett slentrianmässigt sätt och vissa klinter då utsätts för onödiga ASI-intervjuer. I Småstad lyfts detta fram av verksamhetschefen och i Mellanstad, som har använt ASI en längre tid, tar samtliga informanter upp dessa problem. Sektionschefen i Mellanstad anser, med hänvisningar till reaktioner från personalen, att det finns fall där klienterna har utsatts för övergrepp. Det framkommer också att personalomsättning är ett problem. Handläggaren i Småstad berättar att i nuläget är det bara en av fyra handläggare som är utbildad för ASI.

\section{Steg II}

När det gäller de individuella uppföljningsintervjuerna finns retoriskt ett relativt stort stöd. I båda kommunerna säger de intervjuade att meningen är att de skall göras enligt planen. Emellertid sker det i begränsad omfattning. Ju mer konkreta svaren blir desto klarare framstår uppföljningsintervjuerna som en ambition snarare än faktisk praktik. En anledning till detta är att steg II inte alltid prioriteras av handläggarna. Varken i Mellanstad eller i Småstad ses den individuella uppföljningen som ett viktigt motiv att använda ASI. Uppföljningen prioriteras främst av nivåerna högre upp i organisationen. Även om inställningen till ASI överlag är positiv anser flera handläggare att klienterna inte skall behöva genomgå allt för många ASI-intervjuer. Uttrycket "ASI-terror", används. Handläggarna bedömer alltså att intervjun innebär en viss kostnad för individen. Den direkta klientkontakten gör att det tar emot att utsätta klienterna för sådant som uppfattas som negativt. Är personen som förväntas göra uppföljningsintervjun också den som har minst incitament att göra den ökar naturligtvis risken för att den inte blir gjord.

De två kommunerna har gjort olika organisatoriska val: I Mellanstad ansvarar den socialsekreterare som gjort den första intervjun också för att den uppföljande intervjun. Det innebär att en relativt liten grupp genomför ett relativt stort antal intervjuer. I Småstad däremot genomförs uppföljningsintervjun av behandlare på den enhet där klienten befinner sig, vilket sannolikt ytterligare minskar incitamentet att utföra den. Fås mycket information vid den första klientintervjun upplevs den som berättigad. Däremot är det mer tveksamt, om den som träffar klienten varje dag i en behandlingskontakt, upplever att uppföljningsintervjun ger mycket information utöver den man redan har.

\section{Steg III}

Gruppsammanställningar talas det positivt om och stora förhoppningar knyts till dem. Båda kommunerna har kommit en bit på väg med att göra gruppsammanställning och man knyter stora förhoppningar till dem. I Mellanstad finns gruppsammanställningar i form av tvärsnittsanalyser av klienterna på en av öppenvårdsenheterna ett antal gånger. Sammanställningarna har fungerat som en inspiration även för Småstad. Informanternas uppfattningar om vilka deras typiska klienter är förefaller dock inte vara baserade på gruppsammanställningar av klienterna. Bilden av de typiska klienterna är ganska vag och allmän. Någon pekar ut marginaliserade människor med psykiska problem, någon annan ungdomar, en tredje vuxna kvinnorna som en liten men växande grupp, medan ytterligare någon säger att det är 
väldigt mångfacetterat. Beskrivningarna är svepande och samtidigt påfallande lika i de två kommunerna, vilket antyder att detta är en allmängiltig bild av vilka missbruksklienterna är, som dock inte är baserad på den kunskap som ASI ger.

Vår samlade bild är därför att den stora merparten av klientintervjuerna inte är sammanställda. Småstad, som inte hållit på lika länge som Mellanstad, väntar på resultaten av sin första gruppsammanställning. Också viss kritik mot detta sätt att arbeta framkommer. Bl.a. nämns att det är oetiska att göra intervjuer med individer om huvudsyftet är att erhålla gruppsammanställningar.

Möjligheten att göra verksamhetsuppföljningar påverkas av att det finns ett motstånd mot att utsätta klienterna för alltför täta ASI-intervjuer och att de som behandlare uppfattar informationen som mindre värdefull. Vidare framkommer att verksamheterna periodvis kan vara ganska instabila. När politikern i Småstad tillfrågas om hon fått information om en av öppenvårdsenheterna berättar hon att den fått stänga. Efter en tid öppnade den igen men då bara delar av den. I en värld med ganska små och instabila vårdenheter är det tveksamt om man kan nå upp till den kvalitet och omfattning som $\mathrm{Ny}$ ström m.fl. (2003) anser måste till för att informationen skall kunna användas för verksamhetsutvärderingar. För att kunna göra jämförelser och uppföljning krävs, förutom kompetens hos dem som genomför intervjuerna, också möjlighet att göra tillräckligt många intervjuer. Mycket talar för att detta är svårt att uppnå i en normalstor svensk kommun.

\section{Samstämmighet och kontroll}

För att förstå orsakerna till skillnaden mellan retorik och praktik är de förväntningar som ställs på handläggarna viktiga att studera, vilken nytta de olika hierarkiska nivåerna ser med ASI, liksom vilken uppföljning som görs av hur ASI används.

\section{- Förväntningar på handläggarna}

Synen på handläggarnas uppgift är sammansatt. I Mellanstad ges en relativt enhetlig bild: Handläggarna skall på ett respektfullt sätt och utifrån individens förutsättningar utreda och bedöma klienternas insatsbehov. Utöver detta nämner verksamhetschefen och sektionschefen att en viktig uppgift handläggarna har är att föra informationen uppåt i organisationen. De som är högst i organisationen, politikern och verksamhetschefen, betonar att handläggaren skall sätta individen i centrum. En intervjuad handläggare i Mellanstad uttrycker däremot att möjligheter till det är begränsade genom att hon delvis är hänvisad till att erbjuda kommunens befintliga öppenvårdsinsatser. Även i Småstad fokuserar politikern och verksamhetschefen på handläggarens relation till klienten som den viktigaste uppgiften medan den biträdande verksamhetschefen och även handläggaren betonar att den viktigaste, om inte den enda uppgiften, är att svara mot de mål som socialtjänstlagen och nämnden satt upp. I båda kommunerna råder således dubbla förväntningar på handläggarna. De skall sätta klienten och hans/hennes behov i fokus men samtidigt se till att behoven tillfredsställs på det sätt som socialnämnden anger.

Hur skall man utifrån den ovanstående beskrivningen förstå användningen av ASI och de problem som kan uppstå vid 
implementeringen av den? Det finns olika syn inom organisationen på framför allt handläggarnas uppgifter. Även om alla på ett ytligt plan verkar vara samstämmiga tycks handläggarna i det konkreta arbetet leva med dubbla roller. Att införa ASI kan medverka till att göra handläggarens roll tydligare och öka samsynen på vad socialt arbete är. ASI kan därför bidra till att stärka handläggarnas känsla av professionalitet. Samtidigt kan ASI-intervjun aktualisera den motsättning som finns mellan handläggarens olika roller. Om resultaten av ASI-intervjun visar på behov av en vårdform som socialnämnden i princip sagt nej till, hur skall handläggaren ställa sig då? Om handläggaren tycker att det för klienten är bäst att slippa fler ASI-intervjuer men ledningen behöver informationen i syfte att utveckla verksamheten, vems intresse väger tyngst? Motsättningarna gör det begripligt att handläggarna har en låg motivation att göra uppföljningsintervjuer med klienter, som de tycker att de känner väl och träffat många gånger så länge de inte upplever att uppföljningsintervjuerna kommer klienterna till godo.

\section{- Politiker och ledning om implementering och kontroll av ASI- användningen}

Båda politikerna berättar att de är positiva till ASI. De ser användning av bedömningsinstrument som en viktig metod i det sociala arbetet. Ingen av politikerna är dock säker på om ett formellt politiskt beslut att använda ASI har fattats. Gemensamt för de båda kommunerna är också att införandet av ASI har drivits av verksamheternas ledning. Så väl politiker som ledning varnar dock för att ASI, om den görs av slentrian eller på andra sätt fel, kan vara till skada för klienterna och verksamheten. En central fråga blir vilken kontroll politikerna har över hur användningen av ASI går till, eftersom den tydligen kan vara ett tveeggat svärd. Verksamhetschefen i Mellanstad säger att politikerna har varit positiva till ASI men att de sedan inte brydde sig så mycket mer. Han anser att förvaltningsledningen förmedlat information till politikerna om hur användandet fortskrider men att politikerna gärna kunde ha efterfrågat mer information. Verksamhetschefen säger också att de sammanställt rapporter om verksamheten baserade på ASI, t.ex. över problematiken hos dem som gått på en öppenvårdsenhet. Politikern i Mellanstad menar dock att han inte fått någon sådan fördjupad statistik. Däremot är han medveten om diskussionen om eventuella negativa effekter vid inledningsskedet av ASI-användningen. Han utgår dock från att arbetet fortskrider på ett positivt sätt eftersom han inte fått någon information som skulle peka på motsatsen. Han har inte märkt att förvaltningen har ändrat arbetssätt sedan ASI infördes men han hoppas att handläggarna känner sig säkrare och att bedömningarna har blivit mer likformiga utan att handläggarna tappat individperspektivet. Intervjuerna med politikern och verksamhetschefen i Mellanstad ger ett intryck av att kontrollen av hur ASI-användningen fortskrider är svag från politikernivån. Projektet har pågått under 7 års tid med varierande intensitet. Trots att politikern upplever att han inte fått statistik på gruppnivå, vilket han tycker är viktigt, kräver han inte någon konkret information utan förlitar sig på att användningen fungerar.

Situationen i Småstad är både lik och 
olik situationen i Mellanstad. Politikern i Småstad är också positiv till ASI och berättar att socialnämnden fattat beslut att använda ASI. Hon nämner däremot inte särskilt verksamhetsutveckling som motiv för ASI-användningen. Politikern säger att hon redan tidigare fick bra information om verksamheten. Hennes förhoppning och tilltro till ASI handlar främst om att det skall bli rättvisare och mer likformiga klientbedömningar. Hon ser också ASI som en liten morot för personalen, som därmed kanske kan göra bättre utredningar och bidra till utveckling av verksamheten. Även om hennes motiv är annorlunda framträder inget intresse av att följa upp verksamheten. När hon tillfrågades om det var några initialsvårigheter vid införandet svarar hon att hon inte vet, eftersom hon inte frågat. Att socialnämndens politiker inte har ställt frågor beror på att de är inställda på att det skall gå bra, säger hon.

Verksamhetschefen kan inte minnas att han skulle ha gett någon information om implementeringen av ASI till socialnämnden och säger att politikerna inte heller har frågat efter någon som baserar sig på ASI-intervjun. Både politikern och verksamhetschefen utgår från att samtliga handläggare använder ASI, med eventuellt undantag för någon nyanställd. Emellertid berättar en intervjuad handläggare i Småstad att han är den ende som för tillfället använder ASI. Politikern och verksamhetschefen i Småstad utgår från att inställningen till ASI är positiv bland personalen, eftersom inget annat framkommit. Intervjuerna med personalen visar dock att det funnits missnöje. Delar av personalen ville inte använda instrumentet och fortfarande finns de som inte använder instrumentet i den utsträckning som planerats. Politikern har en ganska oklar bild av huruvida arbetssättet har förändrats. Hon tror inte att det har ändrats men hoppas att systemet blivit mer rättvist även om hon inte märkt någon konkret skillnad. Verksamhetschefen är inte säker på om arbetssättet har förändrats men han hoppas att umgänget mellan behandlare, handläggare och klient har utvecklats positivt, ungefär som i Engströms studie som han tagit del av. Detta är dock inte något man har undersökt i Småstad.

Våra intervjupersoner poängterar alla att ASI-intervjuerna är viktiga. Ändå framkommer det att politikerna inte verkar bry sig nämnvärt om hur användandet fortskrider. Det ges ofta sken av att ASI används mer än vad som förefaller att vara fallet i praktiken. Även om vi inte har talat med alla handläggare förefaller det inte troligt att de som valdes ut för intervjun av en positiv ledning skulle använda ASI i avsevärt mindre omfattning än sina kollegor. Motiven för att använda ASI är bl.a. av att socialarbetaren skall framstå som mer professionell och att hela socialtjänsten som mer seriös. Verksamhetschefen, som varit drivande i Småstad talar om klientperspektiv och klientmedverkan som viktiga motiv för ASI-intervjun. Han har emellertid själv inte gått utbildningen och känner inte till om man kan hoppa över inslaget av klientmedverkan eller inte. Ett annat tecken på att bedömningsinstrumenten införts i en "retorisk" anda är att nästan alla talar om att det finns en risk för att bedömningsinstrument kan vara negativa om de används slentrianmässigt, något som det varnas för i litteraturen. I organisationer där ASI-intervjuerna inte genomförs i större omfattning än i Små- 
stad och Mellanstad torde slentrian dock inte vara det största problemet, snarare är det att upprätthålla tillräcklig kvalitet i intervjuerna.

Sammanfattningsvis framkommer att det inte finns någon struktur för att kontrollera om, och i så fall hur, ASI används. Både politiker och ledning litar på att det sker på det sätt som det är tänkt enligt en ideal modell. Så länge resultat inte efterfrågas och inte heller verkar behövas för beslutsfattandet är det begripligt att användningen inte blir mer omfattande och att ASI:s potential inte utnyttjas.

\section{Avslutande diskussion}

Vi har beskrivit hur ASI används i två svenska kommuner och även sagt något om vilka förutsättningar för användningen är. Genom att ställa Socialstyrelsen ideala bild av hur ASI kan användas och genom en nyinstitutionell teoretisk ansats har vi beskrivit hur ASI används i två svenska kommuner och även sagt något om vilka förutsättningarna för användningen är för att därigenom i någon mån kasta ljus över varför den ser ut som den gör. Vår studies begränsning utgörs av ett ringa antal informanter i två kommuner liksom att den ger en ögonblicksbild av läget. Trots detta menar vi att vi har pekat på en rad väsentliga problem förknippat med ASI.

Vi har sett att det för vanliga svenska kommuner av Mellanstads och Småstads storlek finns flera hinder för att använda ASI enligt den ideala modellen. Avseende det första steget, klientbedömningar, finns det skäl att fråga om det finns tillräcklig variation i behandlingsinsatserna för att det skall vara motiverat att undersöka klienternas behov inom olika livsområden. Med tanke på den låga genomströmningen av klienter i socialtjänstens missbrukarvård (Blomqvist m.fl. 2007) kanske inte heller klienterna alla gånger är motiverade att besvara instrumentets frågor om resultatet av bedömningen ändå resulterar i samma behandlingsinsatser, som de sedan tidigare har misslyckade erfarenheter av (se också Storbjörk 2007).

En annan fråga är hur det skall vara möjligt att upprätthålla tillräcklig kvalitet på klientbedömningarna. Flera av våra informanter för fram att det inte är lämpligt att använda instrumenten om intervjuaren är negativt inställd En utbredd uppfattning finns också om att instrumenten inte är lämpliga att använda för alla klienter, t.ex. de som har språksvårigheter, är psykiskt labila eller förståndshandikappade. Med tanke på personalomsättningen i missbrukarvården är det dessutom svårt att upprätthålla den kompetens som krävs för att säkerställa kvaliteten på intervjuerna. Detta problem kan lösas genom olika organisatoriska val. Den ena möjligheten är att en mindre grupp står för genomförandet av intervjuerna och därmed ökar kvaliteten på dem. Nackdelen är då att den information som själva intervjutillfället ger begränsas till denna lilla grupp, som blir sårbar för personalförändringar eftersom deras särskilda kompetens inte utan vidare kan ersättas av andra. Den andra möjligheten är att den person som är ansvarig för behandlingen genomför intervjun. Denne kan då tillgodogöra sig den tilläggsinformation som framkommer under intervjun. Problemet är då att antalet genomförda intervjuer blir för lågt för att kvaliteten i intervjuerna skall kunna upprätthållas. Knutet till detta är också problemet om klientbedömningsintervjuerna ger olika resultat beroende på vem 
som genomför dem. Flera personer i Mellanstad och Småstad har erfarenhet av att resultaten skiljer sig åt beroende på vem som utfört bedömningen.

Avseende det andra steget, uppföljningsintervjuerna, innebär det ett problem att handläggarna eller behandlarna, som skall genomföra intervjuerna inte upplever samma nytta med dessa som nivåerna högre upp i organisationen. Handläggare/behandlare bedömer också klientens utsatthet i intervjusituationen som större än vad personalen på högre organisationsnivå gör. Vidare är de faktiska förhållandena besvärligare, särskilt i Småstad där användningen är utspridd på relativt många personer. Var och en erbjuds därför endast få tillfällen att genomföra intervjuer. Bedömningsinstrumenten riskerar då snarare att öka osäkerheten vid klientmötena istället för att minska den.

Avseende det tredje steget, att använda resultaten för att göra sammanställningar på gruppnivå, uppstår fler problem. Eftersom det tredje steget är beroende av att det första steget har genomförts är det behäftat med samma problem som det första. Ytterligare problem är att det är osäkert om de som är ansvariga för att göra intervjuerna är tillräckligt motiverade, särskilt om de upplever att intervjun inte i första hand kommer deras klienter till gagn. Ett annat problem är att det krävs många intervjuer för att det skall vara meningsfullt att försöka göra gruppsammanställningar eller aggregera behandlingsresultat. Med hänsyn till den ovisshet som följer med varje steg i användningen av bedömningsinstrumentet är det osäkert om det är möjligt att åstadkomma ett tillräckligt stort underlag med godtagbar kvalitet. Därtill kommer att kommunerna kontinuerligt genomför organisationsförändringar av verksamheten. Det torde därför vara tveksamt om det är möjligt att över tid genomföra intervjuer i tillräcklig omfattning och med tillräcklig kvalitet för att kunna uttala sig om en verksamhets behandlingseffekter.

Slutligen kan ett problem knytas till frågan om den information som framkommer vid intervjuerna efterfrågas eller inte. Upplever handläggarna att informationen kan användas? Känner chefer och politiker att informationen är nödvändig? Som framkommit ger handläggarna uttryck för dubbelhet inför användandet. Ibland upplevs den strukturerade intervjun som ett stöd i arbetet och ibland att den information de får inte rättfärdiga den utfrågning som klienten utsätts för. Politiker och chefer är mycket positiva till användning av ASI när de talar om den men de visar inte prov på att vara intresserade av hur användningen fortskrider eller av att efterfråga och ta tillvara den information som ASI-intervjuerna medger.

I våra intervjuer framträder en diskrepans mellan retorik och praktik. Intervjupersonerna är övertygade om att ASI är viktigt för att utveckla arbetet och att uppföljning är A och O. Ändå varnar de för ASI:s negativa effekter för klienterna. Trots de kritiska funderingar som emellanåt återfinns bland våra informanter är den samlade bilden en övergripande tilltro till ASI på alla nivåerna av organisationen i Mellanstad och Småstad och användningen har organisationens stöd. Ändå, trots övertygelsen om ASI:s positiva kvaliteter och trots de farhågor som framförs efterfrågas mycket lite information om hur användandet fortskrider och vad för slags information intervjuerna ger. 
Övertygelsen om ASI:s positiva kvaliteter förefaller därför mindre hämtad från de egna praktiska erfarenheterna av ASI än från de drivande centrala aktörerna IMS och Socialstyrelsen.

Skillnaden mellan retorik och praktik kan delvis förstås genom ett nyinstitutionellt teorietiskt ramverk. En människovårdande organisation som socialtjänsten, som är svår att utvärdera och bedöma, kan för att hantera de egna och omgivningens motstridiga krav på hur organisationen bör arbeta ansluta sig till idéer om arbetssätt som är legitimitetsskapande för verksamheten, trots att detta arbetsätt inte kommer till nytta i den verksamhet organisationen bedriver. Förklaringen till den skillnad som framträder mellan ASI:s retorik och praktik kan därför finnas i de särskild krav som ställs på människovårdande organisationers trovärdighet och legitimitet. Det finns en spänning mellan å ena sidan de förväntningar, normer och värderingar som uttrycks från omgivningen på hur organisationen bör arbeta och å andra sidan de metoder och tekniker organisationen använder för att lösa vissa arbetsuppgifter. Ur ett legitimitetsperspektiv blir det viktigare för organisationens överlevnad att få omgivningens stöd än att leva upp till tekniska krav på effektivitet (Johansson 2002). Omgivningens krav på organisationen kan emellertid vara konkurrerande och motsägelsefulla och komma från en rad olika grupper som statmakten, politiker, enskilda brukare, andra professionella, allmänheten och inte minst media. Ett sätt för organisationen att hantera motstridiga krav är att skapa en lös koppling mellan det man säger att man gör och det man faktiskt gör. Fördelen är att genom den lösa kopplingen kan organisationen skapa legitimitet utåt och samtidigt låta det vardagliga arbetet styras av mer praktiska överväganden (se t.ex. Ineland 2006; Johansson 1992). Det sätt på vilket ASI implementerats och används i Mellanstad och Småstad utgör exempel på fördelarna med en lös koppling mellan det man säger att man gör och det man gör: Man kan på en retorisk nivå anamma ett nytt arbetssätt utan att behöva ändra arbetssätt i praktiken.

Standardiserade bedömningsmetoder kan ses som en del av socialtjänstens ambition att arbeta "evidensbaserat" och svara mot den omfattande kritik som riktats mot missbrukarvårdens tillkortakommanden. Användning av standardiserade bedömningsinstrument är också ett sätt att möta krav på att verksamheten skall vara utvärderingsbar, konkurrenskraftig och uppföljningsbar i en bred mening. Ytterst handlar det om en organisations legitimitet i förhållande till andra organisationer som konkurrerar på samma fält, t.ex. hälso- och sjukvården. Standardiserade bedömningsinstrument tycks retoriskt ha mycket att erbjuda: matchning, neutralitet, möjligheter till uppföljning och utvärdering, som bör tilltala en ifrågasatt verksamhet. Praktiskt tycks de ha mindre att erbjuda, som vår undersökning av användningen i Mellanstad och Småstad visar.

Genom intervjuerna i de två kommunerna framträder missbrukarvårdens önskemål att utföra ett professionellt arbete som leder till att människor som har problem med alkohol och droger får adekvata insatser. En väl genomförd dokumentation av klienternas problem och vilka insatserna är för att avhjälpa dessa problem är ett steg i en sådan process. Vår undersök- 
ning visar dock på många hinder av strukturell och organisatorisk karaktär för systematisk användning av standardiserade bedömningsinstrument. De viktigaste av dessa är att det är svårt att upprätthålla en hög kvalitet på intervjuerna på grund av hög personalomsättning och relativt få tillfällen att göra intervjuer. Det är också svårt att få personalen att genomföra uppföljningarna då nyttan av dem för klienterna inte är självklar. Ett särskilt hinder för att göra verksamhetsuppföljningar, i tillägg till de redan nämnda, består av att verksamheterna är små och föränderliga.
Därtill kommer en bristande variation i behandlingsutbudet och inte minst budgetrestriktioner. Användningen av ASI tycks därför inte erbjuda en enkel lösning för att bryta med de problem svensk missbrukarvård brottats med det senaste seklet.

Maria Abrahamson, Docent, forskare

SoRAD, Stockholms universitet,

S-10691 Stockholm, Sverige

E-post: maria.abrahamson@sorad.su.se

Kalle Tryggvesson, forskare

SoRAD, Stockholms universitet,

S-10691 Stockholm, Sverige

E-post: kalle.tryggvesson@sorad.su.se

\section{NOTER}

1) I artikeln kommer vi inte att beröra de psykometriska aspekterna av ASI utan nämner här endast att ASI har varit föremål för en hel del metodologisk kritik, den mest genomgripande av Mäkelä (2004) som redovisar en forskningsöversikt av 37 olika studier som diskuterar ASI:s reliabilitet och validitet. Mäkeläs slutsats är en avrådan från att använda ASI i forskningssyfte eller som underlag för kliniskt beslutsfattande. Den nytta Mäkelä ser med ASI är att användningen har brutit ett tidigare motstånd hos professionella i behandlingssystemen mot att systematiskt samla in uppgifter om klienter/patienter. En diskussion om olika aspekter av ASI finns också i ett temanummer av tidskriften Journal of Substance Use 9 nr 3-4, 2004, som består av material från

\section{| REFERENSER}

Abrahamson, M. \& Tryggvesson, K. (2008): Användning av bedömningsinstrument $\mathrm{i}$ missbrukarvården - en nationell kartläggning och fallstudier av två län. Stockholm: Institutet för metoder i socialt arbete (IMS)

Ahrne, G. (1994): Social Organizations. Interaction inside, outside and between organizations. London: Sage Publications

Alexanderson, K. (2006): Vilja, Kunna, Förstå: Om implementering av systematisk dokumentation för verksamhetsutveckling i socialtjänsten. Örebro Studies in Social Work 7. Örebro: Örebro universitet Andréasson, S. \& Lindström, U. \& Armelius, B-Å. \& Larsson, H. \& Berglund, M. \& Rydberg, U. \& Zingmark, D. \& Tengvald, K. 
(1996): ASI - ett sätt att intervjua klienter i missbrukarvården. Socialstyrelsen. CUSskrift 1

Bergmark, A. (2007): Riktlinjer och den evidensbaserade praktiken - en kritisk granskning av de nationella riktlinjerna för missbrukarvård i Sverige. Nordisk alkohol\& narkotikatidskrift 24 (5): 519-529

Bergmark, A. \& Lundström, T. (2007): Att studera rörliga mål - om villkoren för evidens och kunskapsproduktion i socialt arbete. Socionomens forskningssupplement 21: $4-16$

Bergmark, A. \& Oscarsson, L. (1994): Från producenternas paradis till marknadens retorik. I: Pettersson, U. (red.): Socialtjänstens klientarbete. Från vision till marknad? Lund: Studentlitteratur

Blomqvist, J. (2002): Att sluta med narkotika - med och utan behandling. Socialtjänsten Stockholm: FoU-enheten. FoU-rapport 2

Blomqvist, J. (2007): Alkohol- och narkotikaproblem. Några aktuella utmaningar för vårdsystemet. Stockholms stad. Forsknings- och utvecklingsenheten. Kunskapsöversikt 4

Blomqvist, J. \& Oscarsson, L. (2006): Att utvärdera behandlingseffekter vid alkoholmissbruk. Några metodfrågor och deras implikation för behandlings- och riktlinjearbete. I: Faktaunderlag till Nationella riktlinjer för missbruks- och beroendevård. Socialstyrelsen

Broekman, T.G. \& Schippers, G.M. \& Koeter, M.W.J. \& van den Brink, W. (2004): Standardized assessment in substance abuse treatment in the Netherlands. The case of Addiction Severity Index and new developments. Journal of Substance Use 9 (3-4): 147-155

DiMaggio, P. \& Powell, W. (1991): Introduction I: Powell, W \& DiMaggio, P. (red): The New Institutionalism in Organizational Analysis. Chicago: The University of Chicago Press

Engström, C. (2005): Implementering och utvärdering av Addiction Severity Index (ASI) i socialtjänsten. Akademisk avhandling, institutionen för psykologi, Umeå universitet

Engström, C. \& Armelius, B-Å. (2005): Implementering av en strukturerad intervju (ASI) i missbrukarvård och kriminalvård. Social- vetenskaplig tidskrift 12 (1): 27-42

Eriksson, A. \& Palm, J. \& Storbjörk, J. (2003): Kvinnor och män i svensk missbruksbehandling: en beskrivning av klientgruppen inom socialtjänstens missbrukarvård i Stockholms län 2001-2002. Stockholms universitet. Centrum för socialvetenskaplig alkohol- och drogforskning (SoRAD). SoRAD-rapport 15

FoU-nordväst (2008): Implementering av Addiction Severity Index (ASI) i åtta kommuner i nordvästra Stockholm - erfarenheter \& resultat. Slutrapport från ett tvåårsprojekt med medel från Länsstyrelsen. Sollentuna: FoU-nordväst i Stockholms län

Fäldt, J. (2007): Implementeringen av dokumentationssystem och behandlingsmetoder. I: Fäldt, J. \& Storbjörk, J. \& Palm, J. \& Oscarsson, L. \& Stenius, K. (2007): Vårdkedjeprojektet. Tre utvärderingsperspektiv. Stockholm: Statens institutionsstyrelse (SiS) Forskningsrapport 2/2007

Hasenfeld, Y. (1983): Human Service Organizations. University of Michigan: Prentice Hall

Ineland, J. (2006): Konst, funktionshinder och frågan om legitimitet - om nya domänasspråk på handikappfältet. I: Grape, O. \& Blom, B. \& Johansson, R. (red): Organisation och omvärld - nyinstitutionell analys av människobehandlande organisationer. Lund: Studentlitteratur

Johansson, R. (1992): Vid byråkratins gränser. Om handlingsfrihetens organisatoriska begränsningar i klientrelaterat arbete. Lund: Arkiv förlag

Johansson, R. (2002): Nyinstitutionalismen inom organisationsanalysen. En skolbildnings uppkomst, spridning och utveckling. Lund: Studentlitteratur

Johansson, R. (2006): Nyinstitutionell organisationsteori - från sociologi i USA till socialt arbete i Sverige. I: Grape, O. \& Blom, B. \& Johansson, R. (red): Organisation och omvärld - nyinstitutionell analys av människobehandlande organisationer. Lund: Studentlitteratur

Kvale, S. (1997): Den kvalitativa forskningsintervjun. Lund: Studentlitteratur

Lindström, L. (1992): Managing Alcoholism. Matching Clients to Treatments. Oxford: 
Oxford University Press

Lipsky, M. (1980): Street-Level Bureaucracy. Dilemmas of the Individual in Public Services. New York: Russel Sage Foundation

McLellan, A. \& Kushner, H. \& Metzger, D. \& Peters, R. \& Smith, I. \& Grisson, G. \& Pettinatti, H. \& Argeriou, M. (1992): The fifth edition of the Addiction Severity Index. Journal of Substance Abuse Treatment 9: 199-213

Månsson, S.-Å. (2000): Kunskapsutveckling inom socialtjänsten och den akademiska forskningen - drar vi åt samma håll? Socionomen 8

Mäkelä, K. (2004): Studies of the reliability and validity of the Addiction Severity Index. Addiction 99: 398-410

Nyström, S. \& Cronqvist, A.-L. \& Engström. C. \& Jäderland, A. \& Ekblom, G. \& Lood, C. (red.)(2003): Metoder för missbrukarvården. ASI-intervjun i praktisk tillämpning. En rapport från CUS. Stockholm: Socialstyrelsen

Oscarsson, L. \& Stenius, K. (2007): VKP-projektet - några avslutande reflektioner. I: Fäldt, J. \& Storbjörk, J. \& Palm, J. \& Oscarsson, L. \& Stenius, K. (red): Vårdkedjeprojektet. Tre utvärderingsperspektiv. Stockholm: Statens institutionsstyrelse (SiS) FoU. Forskningsrapport $2 / 2007$

Socialstyrelsen (2004): Systematisk bedömning inom socialtjänsten. Stockholm: Socialstyrelsen

Socialstyrelsen (2007): Nationella riktlinjer för missbruks- och beroendevård. Vägledning för socialtjänstens och hälso- och sjukvårdens verksamhet för personer med missbruks- och beroendeproblem. Stockholm: Socialstyrelsen: Nationella riktlinjer för vård, behandling och omsorg

Socialstyrelsen och Länsstyrelserna (2006): Individ- och familjeomsorg. Lägesrapport 2005. Stockholm: Socialstyrelsen

Socialstyrelsen och Länsstyrelserna (2008):
Individ- och familjeomsorg. Lägesrapport 2007. Stockholm: Socialstyrelsen

Socialstyrelsen (2008a): Kvalitetsutveckling i missbruks- och beroendevård. En lägesbeskrivning av arbetet med kvalitetskriterier och vårdöverenskommelser mellan stat och kommun. Socialstyrelsen

Socialstyrelsen (2008b): Missbruks- och beroendevårdens öppenvård (ÖKART) - en nationell kartläggning. Stockholm: Socialstyrelsen

SOU (2004): Tvång och förändring - Rättssäkerhet, vårdens innehåll och eftervård. Slutbetänkande från LVM-utredningen 3. Socialdepartementet

SOU (2005): Personer med tungt missbruk Stimulans till bättre vård och behandling. Bestänkande av utredningen om en vårdöverenskommelse om missbrukarvården. 2005:82 Stockholm: Socialdepartementet

Stenius, K. \& Room, R. (2004): Measuring "addiction" in Europe: The diffusion of the Addiction Severity Index, and its purposes and functions. Journal of Substance Use 9 (3-4): 105-119

Storbjörk, J. (2007): I gränslandet mellan delaktighet och tvång: klienten i projektet. I: Fäldt, J. \& Storbjörk, J. \& Palm, J. \& Oscarsson, L. \& Stenius, K. (red): Vårdkedjeprojektet. Tre utvärderingsperspektiv. Stockholm: Statens institutionsstyrelse (SiS) Forskningsrapport 2/2007

Storbjörk, J. \& Room, R. (2007): The two worlds of alcohol problems: Who is in treatment and who is not. Addiction Research and Theory 16 (1): 67-84

Trinder, L. \& Reynolds, S. (eds.) (2000): Evidence-based practice: a critical appraisal. Oxford: Blackwell Science

Wikström, E. \& Lindberg, K. (2006): Samverkan, vårdkedjor och standardiserade bedömningsinstrument i missbrukarvården. Utvärdering av Modellkommunprojektet. Rapport 20. Mobilisering mot narkotika. 